\title{
The Dilemma of Community Using Medicine and the Performance of BPOM in Medan
}

\author{
Roswita Sitompul \\ Faculty of Law, Universitas Prima Indonesia, Medan, Indonesia \\ roswita_sitompul@yahoo.com
}

\section{Abstract}

Medicine is something that is very important in human life because humans are not always healthy, medicine is something that is consumed by consumers so that human medicine can be healthy and can return to activity because it must be remembered that a body that is physically and mentally healthy can contribute to the State, society and family. This research is a descriptive and empirical normative, where the data collection is carried out by observation, interviews, the results of which are assessed qualitatively and quantitatively so that it can provide an idea of how the actual application of protection to consumers who consume contaminated drugs that can trigger cancer. It turns out that even though there is Law No. 8 of 1999 on Consumer Protection.
Keywords

Dlemma; society, users, drugs, performance

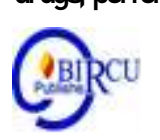

\section{Introduction}

Drugs are very important because drugs are a way to cure illnesses medically, but in fact, even patients who go to the hospital are not a guarantee that the patient is taking drugs in a safe condition, in fact it is the same as drugs that are freely traded in pharmacies. also does not guarantee comfort for the patient. Drug abuse is an endemic disease in modern society, a chronic disease that recurs, which until now has not been found to be universally satisfying, both from the point of prevention, therapy and rehabilitation. (Zulkarnain, 2019)

There is a statement from the BPOM which is very cowardly, especially for patients who frequently consume Ranitidine whose packaging is contaminated with $\mathrm{N}$ Nitrosodimethylamine (NDMA) who are at risk of cancer. The doctor always gives raniditine to every patient who is treated in the hospital because this drug is a treatment for symptoms of stomach acid and intestinal ulcers.Ranitidine is widely available in pharmacies and public health centers, and other drug stores. Ranitidine can be carcinogenic if patients consume it at 92 nanograms regularly.

The community is the only consumer who consumes drugs and has the right to be protected by law and vice versa, the business actor as a provider of goods or services must be responsible for the losses suffered by consumers in consuming goods / services. Many medicines, foods, cosmetics are available for consumption by consumers, but this is not necessarily safe, even with technological advances there are those that offer advertisements promising the robustness of drug use so that they can trick consumers and are interested in consuming them, and vice versa producers in any way will. taken to market their products in order to get a place in the hearts of consumers. In Law Number 8 of 1999 concerning Consumer Protection which aims to protect consumer rights, the right to comfort, security 
and safety in consuming goods and / or services, so that consumers feel comfortable, there is a legal umbrella that protects consumers against the naughty nature of business actors in marketing their medicinal products.

In 2019 BBPOM Medan succeeded in uncovering a syndicate of illegal cosmetic sellers from two different locations and confiscated dozens of types of illegal cosmetic ingredients that were sold online, the illegal cosmetics consisted of 34 items. Also in the case of the drug Albothyl Concentarate which is an over-the-counter drug, there are 38 complaints received by BBPOM from health professionals that they handle patients with complaints of side effects of the albothyl drug which serves to treat canker sores which have serious side effects because the patient consumes it by applying albotyl liquid to the location. canker sores, but as a result the canker sores are enlarged and perforated, causing a noma like lesion to the patient's body.So that BPOM has controlled the drug Raniditin and Albothyl Concentrate by withdrawing the product from circulation.

Also the Head of BBPOM in Medan, Yulius Sacramento Tarigan, who conveyed that the findings of both expired drugs were found at Puskesmas and also drug sales facilities (pharmacies) in the regions. Actually consumer protection is not only protection for individuals, but is protection that is universal (national) for consumers residing in the territory of the Republic of Indonesia. Therefore, it is important to have socialization for consumers about the use of drugs by looking at and observing the instructions for use of each drug which are usually listed on the outer label or inside the medicine box.

In this case who is responsible for these actions which cause harm to consumers who consume drugs or contaminated food which has negative effects that can cause cancer for consumers who consume them. BPOM is an agency formed by the government that must play an active role in carrying out its duties so that in the future ranitidine cases do not occur again in the midst of Indonesian society because public health is very important as one of the assets of our beloved State and Nation of Indonesia.

\section{Research Methods}

This research is normative why there is a dilemma with the case approach, by conducting research aimed more at the legal approach by examining all laws and regulations related to the legal issues being handled. And approach the case by paying attention to cases related to the issues faced which have become court decisions. Data sources are Primary Law materials of Law Number 8 of 1999 concerning Protection of Consumers and Secondary Legal Materials which are sourced from books, legal journals and the internet after all the materials have been collected and analyzed using qualitative techniques so that they can provide a more specific explanation of the dilemma of society. especially against the protection of consumer laws.

\section{Results and Discussion}

In Law No. 8 of 1999 concerning Consumer Protection, there are all efforts that ensure legal certainty to provide protection to consumers, as well as the interests of business actors because the national economy is largely determined by business actors.

Consumer protection is divided into three major parts, namely:

a. rights intended to prevent consumers from loss, both personal loss and property loss,

b. the right to acquire goods at a fair price,

c. the right to obtain an appropriate solution to the problems at hand. 
Indonesia already has an effective and efficient Drug and Food Control System (SisPOM) capable of detecting, preventing and supervising the intended products to protect the safety, safety and health of its consumers both at home and abroad, so BPOM was formed.

BPOM is assigned to

a. issuing distribution permits for products and certificates in accordance with the standards and requirements of safety, efficacy / benefits and quality, as well as drug and food testing in accordance with the provisions of statutory regulations;

b. conduct intelligence and investigations in the field of drug and food control in accordance with the provisions of laws and regulations

c. provide administrative sanctions in accordance with the provisions of laws and regulations.

There needs to be a comprehensive supervision, from the beginning of the process of a product until it is circulated in the community. It is important to hold a three-layer SISPOM, namely;

a. Producer supervision sub-system

Internal supervision from the manufacturers is to ensure good manufacturing practices so that any form of deviation from quality standards can be detected from the start. By law, the manufacturer is responsible for the quality and safety of the products it produces. If there are deviations and violations of the predetermined standards, the producer is subject to legal and administrative sanctions.

b. Consumer supervision sub-system

The supervisory system by the consumer society itself is through increasing awareness and increasing knowledge about the quality of the products it uses and ways of using the products rationally. Supervision by the community itself is very important because in the end it is the community who makes the decision to buy and use a product.

On the one hand, consumers must have knowledge and awareness of the quality and use of a product, and fortify themselves in the use of products that do not meet the requirements, and vice versa, producers must also maintain the quality of the products they produce.

c. Sub-system oversight of the Government / POM

Government supervision system through regulation and standardization; assessment of the safety, efficacy and quality of the product before it is allowed to circulate in Indonesia; inspection, sampling and laboratory testing of circulating products as well as warnings to the public supported by law enforcement. To increase awareness and knowledge of the consumer community on the quality, efficacy and safety of products, the government also carries out communication, information and education activities.

In Article 3 of the Consumer Protection Law, regulates consumer protection, namely:

a. Increase consumer awareness, ability, and independence to protect themselves;

b. Will raise the dignity of consumers by preventing them from negative access to the use of goods and / or services;

c. To promote consumer empowerment in choosing, determining and demanding their rights as consumers;

d. The existence of a legal protection system that provides legal certainty and information disclosure

e. Business actors are expected to be honest and responsible in running their business Domestically produced drugs are drugs that are primarily manufactured and / or packaged by the pharmaceutical industry in Indonesia. 
f. Patent protected drugs are drugs that have obtained patent protection based on the applicable Patent Law in Indonesia.

g. Patented drugs are new drugs that are discovered based on research and development, are produced and marketed under a certain trade name and are protected by patents for at least 20 years.

h. Generic drugs are drugs that can be produced and sold after an innovator drug patent expires. Generic drugs are drugs marketed based on the name of the active ingredient. Branded generic drugs in Indonesia are generic drugs that are marketed under certain trademarks.

i. Traditional medicine is an ingredient or ingredient in the form of plant material, animal material, mineral substance, which has been used for treatment from generation to generation, whose use is considered as a norm in society.

Each drug has its own character, therefore the instructions for use must be clear and correct so that consumers understand, all of this aims to make therapy for patients right on target because there are drugs that contain unstable substances, so there are drugs in the form of tablets or capsules, some are dissolved in the intestine or in the stomach. Each drug has its own label, therefore the patient must know very well if it is in the form of a tablet which must be chewed first

In practice there are several forms of drug dosage, as follows:

a. Some are in the form of powder (pulvis), which is a dry mixture of medicinal substances or refined chemical substances, which are external drugs, not consumed.

b. Pulveres in the form of powder divided by approximately the same weight, wrapped using packaging materials suitable for one drink.

c. Some are in the form of compressed tablets that contain one type of medicine without additional ingredients in the form of a flat or circular tube, both surfaces are convex or flat.

Each drug must be in accordance with good drug manufacturing (CPOB), the purpose of CPOB is to produce high quality drugs, process efficiency, performance productivity, and occupational safety and health.

The existence of good drug standards, namely:

1) Guaranteed safety (safety):

a) Does not contain chemicals harmful to the human body

b) Drug free

2) Effectiveness: effective, quality has met the requirements of both the dosage and the raw material.

3) The existence of Stability means: remain stable with an arbitrary timeframe that can be stored.

4) Appearance matters in terms of: be it color, smell and taste.

CPOB has 12 scopes that must be fulfilled in order for the Head of the Food and

Drug Supervisory Agency to issue a CPOTB or CPOB certificate for drug producers, namely, good quality management, personnel, availability of adequate facilities and buildings, equipment, sanitation and hygiene, resulting in good production., there is quality control, self-inspection and quality audits, how to handle complaints against products thrown in the community, withdrawal of products that have been circulated in the community, and the existence of documentation and analysis of validation and qualifications in contracts.

This BPOM has a role to:

a. Set regulation and standardization. 
b. Issuance of industrial licenses and certifications in the field of Pharmacy based on good production methods.

c. Conduct a product evaluation before it is allowed to circulate.

d. It is a vigilance marketing post covering laboratory inspection, production and distribution facilities and law enforcement.

e. Audit and post audit of advertising and production.

f. Conduct research on the implementation of food and drug control policies.

g. Creating communication, information and public education including public warnings.

BPOM as a government organ is tasked with supervising all drug and food circulation in the market, this supervision is from upstream to downstream, it is necessary to have good cooperation between law enforcers and related agencies responsible for standards, especially regarding sophisticated and high-risk products such as drugs. The health expert's statement that there was a drug containing dangerous substances, the drug in question was a ranitidine drug contaminated with N Nitrosody Methy Lamine (NDMA), BPOM allowed the circulation of Ranitidine medicine in 1989, this drug was in the form of tablets, syrup and injection.

On September 13, 2019, there was a statement from the US FDA which stated that low levels of N Nitrosodiumethylamine or NDMA had been found in several Raniditin products as well as the Zantac brand. NDMA is a substance that is a carcinogen for humans (a substance that can trigger cancer). Based on laboratory test results, NDMA is known as an environmental pollutant that can be found in water and food, including meat, milk and vegetables.

The Health Sciences Authority (HSA) Singapore ordered to stop the sale of 8 brands of Raniditin drugs because they contain NDMA above the normal limit in circulation worldwide. BPOM takes action by providing guidance through counseling and socialization related to the impact of contaminated drugs that can cause cancer risk and ordering drug manufacturers, namely PT. Pharos Indonesia to withdraw all drugs in circulation.

There are several brands of Raniditin that are withdrawn from circulation, namely:

1. Raniditin $25 \mathrm{mg} / \mathrm{ml}$ injection liquid that is distributed by PT.Phapros Tbk.

2. Zantac Liquid Injection $25 \mathrm{mg} / \mathrm{ml}$ circulated by PT Glaxo Wellcome Indonesia

3. $75 \mathrm{mg} / 5 \mathrm{~m}$ rinadine syrup circulated by PT.Global Multi Pharmalab

4. Indoran $25 \mathrm{mh} / \mathrm{ml}$ injection fluid circulated by PT.Indofarma

5. Raniditine liquid injection $25 \mathrm{mg} / \mathrm{ml}$ circulated by PT.Indofarma

6. Radin 150mg tablets by PT Dexa Medica

\subsection{Legal Effort}

Some countries have a special agency or institution to resolve this case, such as in England, Hong Kong, and Sweden, which are known as institutions "Small Claim Carf"(Small Consumer Court), in the Netherlands is known as the "Chillen Commissie" (Small Consumer Settlement Commission). How in Indonesia?

The occurrence of consumer disputes due to consumer dissatisfaction with a product, causing losses in the form of bodily defects (personal injury), physical disabilities (injury to the product it self), and economic losses (pure economic loss). Disability is the inherent loss of a consumer as a result of consuming a product. For example, the case of poisoned biscuits that occurred in 1989 has claimed dozens of lives.

Consumers who feel their rights have been violated need to complain to the NonGovernmental Organization of Consumer Protection (LPKSM) or the Consumer Dispute Resolution Agency (BPSK) or visit the complaint service sub-directorate (sub-directorate) 
at the Consumer Protection Directorate, Ministry of Trade. website officially, http://pkditjenpdn.depdag.go.id, consumers who will complain about the problem by:

a. Via Phone

b. Come Directly to the Sub-Directorate for Complaints Services at the Consumer Protection Directorate.

c. Mass media

d. Internet

Complaints can be written or oral, the complaint will be registered, the registration process is carried out, the registration is carried out, and the consumer is studying the problem. If it turns out that the problem has not yet met the point of clarity, it is necessary to take the following steps:

1. Mediation, which involves a third party who is in a neutral position, is helpful, but does not make a decision.

2. Conciliation, which is carried out by both parties is also accompanied by a third party who acts as conciliator. The decision on compensation is determined by the consumer business actor.

If both fail then delegated to:

1. Consumer Dispute Resolution Agency (BPSK).

2. Carry out a formal juridical (court) route.

Consumers can sue producers through general courts, the parties who can file a lawsuit are:

1. Affected consumers or their heirs.

2. A group of consumers have the same interest.

3. Non-governmental consumer protection organizations in the form of legal entities or foundations

4. Related agencies if the use of the product results in great losses and significant casualties.

There are two forms of consumer dispute resolution, namely through court channels or outside court channels.

a. Filing a class action lawsuit through general courts based on Perma No.1 of 2002 is considered more effective and efficient in resolving legal violations that harm many people.

The requirements that are met for a class action lawsuit against the judiciary are:

1. Numerosity, the number of plaintiffs must be quite large. If submitted individually, it no longer reflects the process of proceeding efficiently.

2. CommonolityThis means that there are similarities between the parties represented by the parties and those who represent them.

3. Typicality, there are similarities in the types of lawsuits and the basis of defense used between class members and class representatives.

4. Adequacy of representation, the feasibility of class representative in representing class members. This measure of eligibility is left to the judge's judgment.

The meaning of Class Action is that some people file a lawsuit in which they feel that they have been harmed by a product so that they demand compensation in court not for themselves but also for everyone who has suffered the same loss, but the difficulty in this method is that it is difficult to determine the person who was injured. if the lawsuit is accepted, the court must open a list where people who feel aggrieved by the same thing register themselves, which is time consuming and expensive. 


\section{b. Citizen Lawsuit}

With the Citizien Lawsuit, everyone can file a lawsuit in the public interest based on PERMA No.2 of 2019, the basis of which the lawsuit is onrecht Matige overhead daad which was carried out by the government (1365) due to the failure of the government to carry out its obligations in implementing a statutory regulation. In Government Regulation Number 80 of 2017 concerning the Food and Drug Supervisory Agency regulates that BPOM must monitor and supervise drugs during circulation whose properties, quality and benefits are guaranteed the same and are the same when given a distribution permit, but apparently BPOM was negligent and did not even know that raniditine had been contaminated. can cause cancer. In the Citizen Lawsuit petitum, there is no claim for compensation, but asks the government to make new decrees for the benefit of all Indonesian people so that the reniditine case does not happen again in the future.

\subsection{Outside the Court}

The Consumer Dispute Resolution Agency (BPSK) that resolves disputes or disputes between consumers and business actors, Article 54 (4) of the Consumer Law within 21 days must have a decision, final and binding. This means that there are no appeals and cassations and no executorial power and the Court is still open to parties who want to seek justice.

Consumer Protection Law No. 8 of 1999 Article 19 provides that:

1. That business actors must be responsible for providing compensation due to damage, pollution, and loss to consumers due to consuming goods and services produced/traded.

2. The provisions for compensation (paragraph 1) can be in the form of a refund or replacement of goods/services of similar or equivalent value, or health care/provision of compensation in accordance with the provisions of the prevailing laws and regulations.

3. The compensation is implemented within a grace period of 7 (seven) days after the transaction date.

4. The compensation in paragraphs 1 and 2 does not eliminate the possibility of a criminal charge based on further evidence regarding the existence of an element of error.

5. Paragraph (1) (2) does not apply if the business actor can prove that the mistake is the consumer's fault.

The BPOM is tasked with conducting drug and food surveillance to issue orders to withdraw Ranitidin products which are detected to contain $\mathrm{N}$ Nitrosodimethylamine (NDMA) which is channeled to cause cancer.

In this case, the BPOM has conducted testing of several samples of Ranitidine medicinal products, the results of which have concluded that Ranitidine contains NDMA contaminants that exceed the normal threshold.

BPOM RI as the agency whose function is to conduct post market supervision in the form of routine supervision and special supervision every year receives many consumer complaints through the Consumer Complaint Service Unit (ULPK) which consists of several complaints such as drugs, traditional medicines, dangerous substances such as those found in drugs raniditine and others can be seen in the table below:

Table 1. Types of Consumer Complaints to BBPOM 2018

\begin{tabular}{|l|c|c|c|c|c|c|}
\hline Type of Complaint & \multicolumn{2}{|c|}{ May } & \multicolumn{2}{c|}{ June } & \multicolumn{2}{c|}{ July } \\
\hline Drug & 170 & $11.21 \%$ & 108 & $15.72 \%$ & 222 & $12.54 \%$ \\
\hline Food & 656 & $43.24 \%$ & 283 & $41.19 \%$ & 821 & $46.38 \%$ \\
\hline Traditional medicine & 126 & $8.31 \%$ & 48 & $6.99 \%$ & 106 & $5.99 \%$ \\
\hline
\end{tabular}




\begin{tabular}{|l|c|c|c|c|c|c|}
\hline Cosmetics & 364 & $23.99 \%$ & 155 & $22.56 \%$ & 348 & $19.66 \%$ \\
\hline Health Supplements & 76 & $5.01 \%$ & 40 & $5.82 \%$ & 87 & $4.92 \%$ \\
\hline Drugs & 7 & $0.46 \%$ & 1 & $0.15 \%$ & 10 & $0.56 \%$ \\
\hline Hazardous Materials & 12 & $0.79 \%$ & 2 & $0.29 \%$ & 4 & $0.23 \%$ \\
\hline Medical Devices & 5 & $0.33 \%$ & 1 & $0.15 \%$ & 10 & $0.56 \%$ \\
\hline PKRT & 7 & $0.46 \%$ & 3 & $0.44 \%$ & 4 & $0.23 \%$ \\
\hline General Info & 94 & $6.20 \%$ & 46 & $6.70 \%$ & 158 & $8.93 \%$ \\
\hline
\end{tabular}

Source: Annual Report of the Consumer Complaint Service Unit

Based on the table, it can be seen that the highest consumer complaint is the type of cosmetics as many as 364 with a percentage of $23.99 \%$ in May, followed by food in June as much as 821 with a percentage of $46.38 \%$ in July. Meanwhile, in 2017, consumer complaints with types of drugs increased by a total of 1681 with a percentage of $10.49 \%$. This shows that there is an increase in consumer complaints at BBPOM because the use of drugs that have side effects that can harm consumers is increasing. Then there were 233 complaints of hazardous materials in 2016 with a percentage of $1.51 \%$, while in 2017 it decreased to 150 consumer complaints with a percentage of $0.94 \%$. Thus, it can be seen that drugs containing hazardous substances are still circulating in the community and BPOM is not effective in carrying out its duties to supervise. For people affected by the use of drugs containing hazardous substances, they can file a lawsuit based on product information, this can be seen in the table below:

Table 2. Consumer Complaints Based on Product Information at BPOM 2018

\begin{tabular}{|l|c|c|c|c|c|c|}
\hline Product Information & \multicolumn{2}{|c|}{ May } & \multicolumn{2}{c|}{ June } & \multicolumn{2}{c|}{ July } \\
\hline Pharmacology & 5 & $0.33 \%$ & 1 & $0.15 \%$ & 5 & $0.28 \%$ \\
\hline Quality & 46 & $3.03 \%$ & 28 & $4.08 \%$ & 67 & $3.79 \%$ \\
\hline Legality & 1245 & $82.07 \%$ & 568 & $82.68 \%$ & 1433 & $80.96 \%$ \\
\hline Marking & 27 & $1.78 \%$ & 11 & $1.60 \%$ & 26 & $1.47 \%$ \\
\hline Other Info About Products & 71 & $4.68 \%$ & 30 & $4.37 \%$ & 83 & $4.69 \%$ \\
\hline General Info & 123 & $8.11 \%$ & 49 & $7.13 \%$ & 156 & $8.81 \%$ \\
\hline
\end{tabular}

Source: Annual Report of the Consumer Complaint Service Unit

$\mathrm{BPOM}$, in this case the government can only monitor business actors who have legality, if they do not have legality, BPOM cannot know that there are business actors who make drugs unfit for consumption. However, if it has legality, the business actor will report it to the Provincial Health Office and then the office has data base which is then reported to BPOM, so that BPOM can supervise drugs that do not meet legality. Consumer complaints that are reported to BBPOM based on the profession of each consumer are seen in the table below:

Table 3. Complaints based on the profession of consumers in the community to BPOM THN 2018

\begin{tabular}{|c|c|c|c|c|c|c|}
\hline Consumer Profession & May & \multicolumn{4}{|c|}{ June } & July \\
\hline Pharmacist & 17 & $1.12 \%$ & 8 & $1.16 \%$ & 29 & $1.64 \%$ \\
\hline Doctor & 1 & $0.07 \%$ & 0 & $0.00 \%$ & 1 & $0.06 \%$ \\
\hline
\end{tabular}




\begin{tabular}{|c|c|c|c|c|c|c|}
\hline Other Nakes & 6 & $0.40 \%$ & 1 & $0.15 \%$ & 5 & $0.28 \%$ \\
\hline Household & 24 & $1.58 \%$ & 13 & $1.89 \%$ & 47 & $2.66 \%$ \\
\hline Employees & 221 & $14.57 \%$ & 119 & $17.32 \%$ & 276 & $15.59 \%$ \\
\hline Student / Student & 41 & $2.70 \%$ & 28 & $4.08 \%$ & 33 & $1.86 \%$ \\
\hline Businessmen & 1124 & $74.09 \%$ & 491 & $17.47 \%$ & 1286 & $72.66 \%$ \\
\hline Bachelor of Law & 69 & $4.55 \%$ & 26 & $3.78 \%$ & 71 & $4.01 \%$ \\
\hline Journalist & 0 & $0.00 \%$ & 0 & $0.00 \%$ & 4 & $0.23 \%$ \\
\hline NGOs & 1 & $0.07 \%$ & 0 & $0.00 \%$ & 0 & $0.00 \%$ \\
\hline General & 13 & $0.56 \%$ & 1 & $0.15 \%$ & 18 & $1.02 \%$ \\
\hline
\end{tabular}

Source: Consumer Complaint Service Unit Report

Based on the table above, it can be seen that the highest number of people who filed a lawsuit at the POM Center in Medan from May to June was 1286 business actors at the most with a percentage of $72.66 \%$. This means that business actors have a higher level of awareness in reporting drugs and food that have dangerous side effects to the Consumer Complaint Service Unit, followed by 276 employees with a percentage of $15.59 \%$ and 71 law graduates with a percentage of 4.01 . \% and households as many as 47 people with a percentage of $2.66 \%$. Housewives as many as 47 people with a percentage of $2.66 \%$ followed by a pharmacist as many as 29 people with a percentage of 1 ,

Based on the results of research based on the data in the table, the business actor is well aware of the obligations stipulated by law which must be held accountable as a legal entity acting in implementing the Consumer Law.

\section{Conclusion}

1. The BPOM has not yet functioned as determined by law, even the BPOM itself is not aware of the presence of $\mathrm{N}$ nitro sodimenthy lamine (NDMA) which causes contamination in the packaging of Raniditin drugs. In terms of the government, it must be more sensitive and must have sophisticated tools to be able to detect the effectiveness and safety of drugs in circulation, at any time monitoring is very much needed for the safety of the Indonesian people, which is the main asset of the State.

2. Consumers who feel aggrieved by regularly consuming Raniditin drugs which contain dangerous substances that cause cancer can file a lawsuit through the court or outside the court, the fact is that the follow-up of the Food and Drug Supervisory Agency (BPOM) only issued a decision to suspend distribution permits to PT. Pharos Indonesia, but does not enter the field.

3. Even though the regulations are clear and firm, from a practical point of view in society, legal protection is far from expectations. Because there has not been a single court decision that can be used as jurisproduction in the case of drugs, foods containing substances harmful to the human body, which consumers have received restriction.

\section{References}

Ahmadi Miru dan Sutarman Yodo, 2014, Hukum Perlindungan Konsumen, Rajawali Pers, Jakarta.

Ahmadi Miru. 2011. Prinsip-prinsip perlindungan hukum bagi konsumen di Indonesia. Rajawali Pers. 
Barkatulah, Abdul Hakim. 2008. Hukum Perlindungan Konsumen, Kajian Teoritis dan Perkembangan Pemikiran. Bandung: Nusa Media.

Dhadang Wahyu Kurniawan. 2009. Teknologi Kesediaan Farmasi.Yogyakarta: Graha Ilmu. Husni Syawali dan Neni Sri Imaniyati, Ed. 2000. Hukum Perlindungan Konsumen. Bandung: Mandar Maju.

Khotibul Umam, SH, LL.M. 2010. Penyelesaian Sengketa Diluar Pengadilan. Yogyakarta: Pustaka Yustisia.

Krisyanti, Celina Trisiwi. 2008. Hukum Perlindungan Konsumen. Sinar Grafika. Jakarta.

Mariam Darus Badruszaman. 1986. Perlindungan Konsumen Dilihat dari Sudut Perjanjian Baku. Jakarta: Bina Cipta.

Rahardjo, Satjipto. 2000. Ilmu Hukum. Citra Aditya Bakti, Cetakan ke-V. Bandung.

Santosa, Mas Ahmad. 1997. Konsep dan Penerapan Gugatan Perwakilan (Class Action) Lembaga Pengembangan Hukum Lingkungan. Jakarta.

Sitompul, Roswita. 2020. The Existence Of People's Consulrative Assembly In Indonesia State System In The Pancasila Dmocracy Perspective. Journal Of Advanced Research In Law And Economics, Volume XI Issue 3(49) Summer 2020.

Sitompul, Roswita. 2006. Hukum Perdata Indonesia. Pustaka Bangsa Press. Jakarta Pusat. Sitompul, Roswita. 2021. Implementasi Hukum Kesehatan Indonesia.UNPRI Press.

Sitompul, Roswita. 2021. Badan Hukum Indonesia. UNPRI Press

Siahaan, N.H.T. 2005. Hukum Konsumen: Perlindungan Konsumen dan Tanggungjawab Produk. Panta Rei. Jakarta.

Susanto, Happy. 2008. Hak-Hak Konsumen Jika Dirugikan. Jakarta: Visimedia.

\section{Peraturan Perundang-Undangan}

Undang-undang No. 8 Tahun 1999 Tentang Perlindungan Konsumen.

Undang-undang No. 36 Tahun 2009 Tentang Kesehatan.

Peraturan Presiden No. 80 Tahun 2007 Tentang Badan Pengawas Obat dan Makanan

Peraturan Pemerintah Nomor 58 Tahun 2001 tentang Pembinaan Dan Pengawasan Penyelenggaraan Perlindungan Konsumen.

Peraturan kepala badan pengawas obat dan makanan nomor hk.03.1.23.10.11.08481 tahun 2011 tentang Kriteria dan tata laksana registrasi obat.

Kepres Nomor 103 Tahun 2001 tentang Kedudukan, Tugas, Fungsi, Kewenangan, Susunan Organisasi, dan Tata Kerjalembaga Pemerintah Non Departemen

Undang-Undang Dasar Negara Republik Indonesia Tahun 1945.

Undang-Undang Nomor 36 Tahun 2009 tentang Kesehatan

Peraturan Presiden Nomor 80 Tahun 2017 tentang Badan Pengawas Obat dan Makanan.

Peraturan Badan Pengawas Obat dan Makanan Nomor 34 Tahun 2018 Tentang Pedoman Cara Pembuatan Obat yang Baik (Berita Negara Tahun 2018 Nomor 1600).

Rosmha Widiyani https://health.detik.com/berita-detikhealth/d-4739226/kenapa-ranitidinditarik-dari-peredaran-ini-4-faktanya diakses tgl 18 desember 2019

https://sains.kompas.com/read/2019/10/07/194410923/ranitidin-obat apa-ini-penjelasanahli-dari-fungsi-sampai-alternatifnya diakses 12 januari 2020.

https://smartlegal.id/smarticle/layanan/2018/11/12/mengenal-citizen-law-suit/

https://www.hukumonline.com/berita/baca/lt5191da19d9d8b/hukum-indonesia-sudah-akuikonsep-icitizen-law-suit-i/

https://medanbisnisdaily.com/news/online/read/2019/08/27/84803/bbpom_amankan_sejum lah_obat_kedaluwarsa_dari_puskesmas_dan_apotek_di_sumut/ 